\title{
Discussion on the Waste Resource Utilization and Management in the Country Based on the Observation and Consideration of Ecological Environment Development in Yiyuan Country
}

\author{
Yixiang Chen ${ }^{a}$, Dulin Yin ${ }^{b}$ * and Shengpei Su ${ }^{c}$ \\ Hunan Normal University, Changsha, Hunan Province \\ a15169287873@163.com, bdulinyin@126.com, csushengpei@yahoo.com \\ *Corresponding author
}

Keywords: Rural, Garbage, Resource, Management.

\begin{abstract}
Based on a three-month observation and interview in some villages of Yiyuan County, this paper summarized the current situation of rural ecological environment in China. It was found that there was a great potential for the classification and reuse of rural construction waste. It suggested that waste as biomass should be converted on the spot; waste from synthetic material products should be integratedly processed; waste as solid hazardous should be recycled by producers. In addition, it is necessary to set up the rural household garbage classification collection station and have a management system. Furthermore, activity to popularize scientific knowledge of the garbage resources was urgently needed to be strengthen. Meanwhile, the door-step education of scientific recycling of rubbish resource should start from the kids and strengthen the school demonstration function.
\end{abstract}

With the development of economic and social modernization in China, the number of people living in the countryside is decreasing year by year. It now accounts for about 50 percent of the population in China, while rural land is hundreds of times more than that of city. The source of drinking water and food for the people in the city are supplied from the countryside. It is obvious that the people's food safety fundamentally relays on the countryside, the foothold and sustainable development of ecological civilization construction are also in the countryside. However, with the development of material civilization and economy, a variety of commodities made from underground minerals and through complex chemical and physical processing have also been popularized in rural areas. The resulting waste is a potentially dangerous threaten to ecology. Resource utilization is the fundamental guarantee of ecological civilization. Based on my visiting experience in some villages of Yiyuan in recent three months, this paper will have a discuss on the current situation of rural ecological environment and the scientific resource utilization of several kinds of household garbage.

\section{Current Situation of Rural Ecological Environment}

China has a vast of rural areas, which accounts for about 90 percent of the country's total land area[1]. While the government is focus on rural environment protection, the construction of beautiful villages has been strengthened in recent years. With the concept of green, coordination and sustainable development, a scenery of the beautiful environment and ecology in rural areas are on the road to be complete realized. The woods are thick and the birds are jabbering away, which can be said that the sound winding and three days without end; cement road covered streets and alleys, farewell to the mud in the rain; new house appraisal, spacious and bright, thatched cottage in the tide of The Times submerged; the limpid river has a few return, and fish often play in it. The sight of rubbish flying into the sky has reduced. Under the glow of sunset, children's favorite kites appear in the sky. But now, compared to Tao Yuanming's words that the land is flat, the houses are arranged in order and there are good fields and beautiful ponds and mulberry bamboos and things like that......, the countryside is far from so beautiful. 
The rapid economic development leads to a broken ecological balance, and this is still worsen day by day. Misappropriation and abuse of cultivated land occur from time to time. The discharged waste water is satisfy the environmental standard, the spread of garbage in some river channels can be seen everywhere, and the drinking water of villagers is also affected to varying degrees, the health condition of the people is endangering. In addition, some large-scale poultry farms do not establish waste disposal facilities, a large amount of fecal sewage is discharging into the natural environment without treatment, leading to the pollution of underground water and water eutrophication of rivers, seas and lakes. Smoke from burning straw is often seen rising in the field leading to the waste of resources and pollution of air with smoke and dust. Garbage has become a public hazard. The phenomenon of garbage enclosing villages and dams has not been eradicated. The amount of non-degradable plastic products including agricultural film and white pollutants is not reduced and is still increasing. In general, the rural environment is dirty, messy and poor, and has not been resolved except local areas. In addition, rural garbage collection is difficult, transport is difficult, treatment is difficult and maintenance is also difficult[1].

\section{The Work for Popularizing Scientific Knowledge of Garbage Resources Needs to be Strengthened Urgently}

At present, there are still many problems in rural garbage management. In addition to shortage of financial support, weak awareness of garbage resource recycling from the villagers and poor sanitary infrastructures, there are also insufficient attention paid by local governments to popularization of scientific knowledge[2], which leads to serious problems of material consumption, energy consumption and labor consumption in the operation of waste-treat process, although some garbage treatment methods have been introduced. It hinders the implementation of rural waste resource recycling, so the science popularization work of waste resource recycling needs to be strengthened urgently.

According to the current assessment system for rural ecological environment, the organization and management of popular science at county, township and village level should be established. Villages are the foundation, townships are the main body, then counties take the leading role. Different levels should take different responsibilities, and merge the popularization of scientific knowledge into the beautiful rural construction of politics, economy, culture, moral and ecology. The acknowledge including scientific principles, technical requirement, economic ability, generation benefit, and social value of the whole the recycling process of domestic waste should be widely publicized and deeply rooted in people's mind. Taking typical examples to tell the people waste littering is also harmful to the people who are serving you. For example, as reported in the news, on the eve of the New Year's day of 2018, a sanitation worker in Zhejiang province was cleaning up the garbage, and his hands were corroded by a strong acid chemical in the wrong-disposed trash.

In the development of media on general science for the resource of household garbage, we should not only rely on traditional ways including slogans, posters and textbooks, but also use modern information tools including modern network, mobile communication and wechat to promote education of general science. In terms of the scientific content of recycling household garbage, we should not only offer basic knowledge, but also provide the latest progress of science and technology in this area. Moreover, we should introduce the successful people and experience in innovation and entrepreneurship of household garbage.

\section{Great Potential for the Classification and Reuse of Construction Waste}

Construction wastes are materials including residue, concrete, gravel, brick and tile, mortar, mud, bitumen, waste plastics, scrap metal, bamboo and wood which are produced in the production activities of the construction industry such as demolition, decoration and repair. With accelerating the construction of beautiful countryside and the rapid development of the construction industry, the building wastes are increasing day by day, and the resulting environmental problems are becoming 
more and more serious. In the process of randomly stacking and landfill of construction waste, sewage leaching and leaching by rainwater, as well as soaking of surface water ground waste has caused serious pollution of surrounding surface water and groundwater. The natural decomposition of some organic substances will produce harmful gases. For example, the large amount of sulfuric acid ions contained in waste gypsum will be converted into hydrogen sulfide with the smell of rotten eggs under anaerobic conditions. Bacteria and dust in the garbage drift away with the wind, causing air pollution, and a small amount of from burning construction waste will bring air pollution. Today's general landfill method is adding 2 meters of soil layer on a 8-meter garbage landfill, it is difficult to grow vegetation on the soil layer. Landfill method damages the soil structure and causes land subsidence.

Although the current construction waste exists in many forms, it has great potential to be classified and reused. The national exploration on the resource utilization of construction waste has never stopped, and in recent years, it has been intensified. In order to promote green development and guide the sustainable and healthy development of the construction waste resource utilization industry, the ministry of housing and urban-rural construction, on December 13, 2016, issued the "standard conditions for the construction waste resource utilization industry" and the "administrative measures for the announcement of standard conditions for the construction waste resource utilization industry". The standard conditions establish the qualification for entering the construction waste resource recycling enterprise, sets the threshold for entering the industry, and requires the reuse percentage of the construction waste resource to reach more than $95 \%$.

The integrated factory model[3] of building waste resource utilization has become more and more popular, and rural residents have gradually touched the frontier of science and technology. The integrated model for reusing the construction waste will be made according to the route of "collection, transportation, classification, treatment and reuse". Only when sufficient construction waste is collected can the factory operate. However, villages are generally small and relatively dispersed. it costs a lot to collect construction waste. Therefore, it is necessary to establish the disposal model of rural building waste combining decentralization and concentration. First of all, an easy way is to reduce the amount of construction waste at the source. This requires the villagers to collect and classify construction waste. Secondly, the integrated plant of construction waste resources has a reasonable location, and the distance between the factory and the surrounding villages is the shortest, of course, it should be far away from the residential areas.

After the integrated plant of garbage transportation, all kinds of garbage are treated and reused in the corresponding way. Waste concrete is manufactured from recycled concrete aggregate through primary separation, crushing, high separation, screening, stacking and washing. The waste bricks and tiles are proceeded by separation, metering and batching (adding cement, sand and auxiliary materials), water mixing, vibrating and forming, natural steam curing, inspection and delivery; because it is a kind of clay material, after crushing and grinding into powder material, it has the same activity as volcanic ash, which can be used as concrete admixture material instead of slag powder and gravel powder[4]. Now commonly used stationary jaw crusher dimension is big, big energy consumption, law production, a rusher facilities often need five to six workers to operate. Development of large output, low power consumption of mobile crusher is needed, especially that kind only one person can remotely control. The waste pipes after the demolition of the house are classified according to the material, which can be recycled. Iron and steel scrap can be sent to steel mills, copper and aluminum scrap can be returned to non-ferrous smelters. Organic polymer pipes and pipe fittings can be sent to chemical materials factories and plastic factories for recycling. Asphalt waste can be mixed with heat refining to make recycled asphalt mixture. The wood treated with preservative should be properly treated according to the toxicity and content of preservation. Every kind of construction waste has a reasonable place to go under the corresponding technology, and most of them can be reused effectively.

\section{Biomass Waste Converted on Spot}

Biomass waste is produced in the process of using and consuming biomass, it still belongs to the 
macroscopical category of biomass. According to different sources, rural biomass waste can be divided into three categories: kitchen waste mainly includes leftovers from the household kitchen, kitchen waste, faces and domestic sludge; crop waste, China's crop straw mainly includes corn straw, wheat straw and rice straw; livestock manure. This kind of garbage is most reasonable for local transformation.

Having visited ten villages in Yiyuan country and found that village A and village B have demonstrated the resource utilization of biomass waste. In village A, villagers collect the food scraps separately and feed the chickens and ducks. The rest of biomass waste is composted in landfill sites using bio-reactor technology[4]. In order to prevent the bad smell from influencing the life of the villagers, the landfill site should far away from the residential area, and the surrounding green area should be large, and it should be also covered with film of HPED. The bio-reactor treatment technology is simple, and it is similar to the traditional compost method in rural area, so the villagers have experiences. This technology only needs small investment and can complete recycling of local garbage resources. Piling uo the manure in the fields instead of using fertilizer, it not only optimizes the physical and chemical properties of the soil[5], making the crops grow healthfully and increasing the yield of plants, but also saves lots of investment of fertilizer every year.

When the thick smoke of burning straw in the field is rising everywhere, biogas production in village $B$ is quiet mature. The preprocessed straw, residual vegetable, pig manure and process water were mixed and transported to anaerobic reaction tank. The anaerobic reaction tank is equipped with a middle axis stirring device. The materials in the tank are mixed uniformly, the anaerobic reaction is carried out adequately under proper conditions of alkalinity and temperature. The generated biogas can be used after evolution. Villagers use biogas for lighting and cooking, saving electricity, cutting down trees, preserving fresh and storing cereals. Biogas slags and biogas slurry can prevent and control crop diseases and insects, and can also be used as feed for raising pigs(chickens, fish, etc.), as well as be used for planting crops. A digester can be used for about 20 years, and the digester can not only save fossil energy, improve and protect the environment, but also save fertilizer and pesticide, improve the quantity and quality of crops, and promote the development of the breeding industry. Biomass energy is an important or permanent renewable energy, and the development and utilization of biomass energy is an important guarantee for improving environmental quality and developing circular economy. The production of biogas is the main way to develop biomass energy. If the vast rural make full use of biomass waste like village B to produce biogas, in the future, biomass energy will lead the trend of rural environment-friendly energy.

\section{Synthetic Material Products Waste Should Be Integrated Processing}

With the improvement of economic development and people's consumption level, the consumption structure of villages has changed. The consumption of synthetic materials and packaging waste has increased sharply, causing serious environmental problems. The white pollution caused by abandoned plastics is especially serious. Therefore, the resource management of abandoned paper, plastic, rubber and other synthetic materials waste has become a big focus in the countryside. In recent years, the villagers have changed their attitude towards them, not just threw it away but transformed them into a capital chain in the mode of integrated treatment. We should further improve the mechanism of "classification and reduction by farmers in the source, the cleaning staff regularly come to the villages to collect waste, villages and towns concentrate on the second classification carefully, and district and county classify waste as a whole", actively developing deep-processing and precision processing industries of synthetic materials waste , and developing new materials and appliances of agricultural products, building supplies and storage products in the construction of beautiful villages, it not only develops and saves resources, but also promotes industrial employment, innovates the model of economic growth and improves the enthusiasm and creativity of villagers in the process of resource utilization of synthetic materials waste. 


\section{Solid Hazardous Waste Should Be Purchased from Old Ones}

Hazardous solid waste, or Hazardous waste for short, refers to wastes with characteristics of hazardous waste that are included in the national hazardous waste list or identified according to the hazardous waste appraisal standards and appraisal methods stipulated by the state. We should continue to adhere to the principle of "adapting to local conditions, making overall planning, market orientation and government supports”, and actively carry out the recycling of waste electrical and electronic products in accordance with the requirements of the state and under the leadership of the local government. Recently, Yiyuan is bracing for a wave of replacing old batteries and tubes with new ones. Every village has its own market in certain days, with the support of the county government, household appliances company in the market to collect the old electric and electronic products, with batteries and tube are given priority to, this kind of small equipment can be used for new ones, and big old appliances can acquire a certain amount of money. In this way, the villagers will no longer abandon their batteries and other household appliances, but accumulate and replace them in exchange for economic benefits, this avoids environmental pollution. A new business model should be further established for the planned market operation of solid hazardous waste products after the scrapping of solid hazardous waste products after the scrapping of "customers exchange the old for the new, retailers accept the old and sell the new, and wholesalers transfer them and act together”. We should cross-link the recycling chain in the supply chain, forming active circulating chains.

\section{Establish Scientific Renewable Resources Station and the Company Management}

Agricultural waste, chicken waste and other biomass waste can be converted on spot for recycling, while synthetic material waste needs to be classified and concentrated for large-scale treatment and utilization. Compared with cities, villages are not easy to transport, villages are scattered, and coast of garbage collection and transportation is high. On the basis of meeting the national laws and regulations, GIS can be used for selecting the address scientifically. Geographical information system comprehensively considers the factors of rustic topography and landform, resident distribution, traffic condition and so on, choosing the most scientific and reasonable address to set up renewable resource station, which conforms to public opinion and reduces investment.

The rural synthetic material base waste renewable resource station should be established beside the rural roads, which should be convenient for both the motor transport and the farmers to project. The site should also closes to primary and secondary schools so that students can recycle resources. The area of the renewable resource station should be reasonably designed according to the number of household that can be covered. The classified containers of paper products, rubber plastic fibers, metals, footwear and electronic appliances are set up in the station for primary storage. The containers of paper and rubber plastic fiber shall have packaging facilities and shall be marked after packaging so as to trace the quality of the goods. The types of the rest containers should be ladder-type containers to be placed directly into the trunk of the transport vehicle during transport. Rural sanitation workers are also collectors of renewable resources. They should set up an electronic account of the recycling amount of household synthetic materials based on garbage resources and publish the average data of each household on the Internet. They summarize and settle accounts every quarter, translated into vouchers to buy a variety of daily goods in the shops. A cabinet of the rural renewable resource station is closed daily and opened when it is collected. The building should be able to withstand storms and rain, and the walls show posters for recycling.

A renewable resource sorting station should be set up in the county, connecting the rural areas, national construction, renewable resource companies bid for operation. According to the needs of enterprises in the downstream industrial chain, the primary classified synthetic material base waste is selected and classified, and the downstream enterprises choose and reuse them. The hazardous waste residue is disposed in a concentrated area without harm. The organic waste is transported to plants to recycle energy. The inorganic waste is used as the landfill of suitable buildings. 
Selected companies of renewable resources operate with national tax exemption, and renewable resource processing enterprises are operated by the state tax exemption. As for public buildings and urban infrastructure construction invested by the government, in planed design and bidding these projects shall give priority to the use of renewable resource recycling products.

\section{School Demonstration and Doll Education in Waste Recycling}

In conclusion, the consciousness and behavior of "people" play a major role in the utilization of garbage resources, while education is the fundamental plan to cultivate consciousness and guide behavior. Schools are the subject of education implementation, cultivating the consciousness of garbage resource from the child is beneficial to the development of permanent thinking and deep-rooted habits.

The action of education in Sancha central School of Yiyuan is worth promoting, the school includes first to ninth-grade students in the southern town of Lushan. Students have to spend a day at school waiting for grades and parents' meetings to complete their final exams. I thought the school would be in a mess, but I didn't think the corridors were silent. The teachers in the classrooms were teaching the students, and the blackboard clearly wrote the theme of the course -recycling of garbage. It was later learned that the first class and the last class of the school were equipped with science teachers and moral teachers to teach the students about the utilization of garbage resources to convey the public participation and awareness of starting from me. They also arrange corresponding practical work for students to complete during the holiday. Not only primary and secondary schools for students to strengthen the awareness of garbage resources, kindergartens are also unwilling to lag behind. In the town of visiting south Lushan kindergarten, we have the honor to attend a class of small class, I found that the theme of chapter one is about garbage collection, including garbage dilemma, classification, processing, recycling, etc. Although small baby don't understand the meaning of them, they know the vivid pictures in the book. The course is effective for young children, they packed up the garbage near their seats after school and put them in the trash at the door, and they distinguished recyclable and non-recyclable waste.

In addition to school education, social education is indispensable, especially for villagers with weak ideas of resource circulation. Under the organization of grass-roots governments, the resources of college students in each village can be fully utilized, and advanced theories and technical achievements of garbage classification and resource utilization can be spread by means of special training, discussion and exchange, skill training and knowledge lectures, so as to help villagers master the basic skills of garbage classification. When every villager realizes the importance of waste recycling and puts it into practice, the family education comes into being and naturally passes down from generation to generation and becomes a cultural custom.

\section{Summary}

In recent years, under the guidance of the national policy, the strict supervision from the government and the active cooperation of citizens, the recycling of rural household garbage has been far from scratch. This is in response to the call of general secretary Jinping Xi that "green water and green mountains are the golden mountain and silver mountain". The countryside is becoming more beautiful and the air is fresher. Despite the improvement of China's rural household garbage disposal capacity, the phenomenon of "garbage enclosing villages" still exists. The main causes of this phenomenon are the lack of relevant policy support, the shortage of funds, the immaturity of market mechanism and the weak ideology of villager. It is believed that with the development of economy, the improvement of policies and the improvement of national quality, the green water and green mountains brought by the waste resource management will be all over the countryside. 


\section{References}

[1] Wenyan $\mathrm{Xu}$, The status and measures of rural garbage management under the background of beautiful rural construction, Guide to Economic Research 2017(27):26-28.

[2] Zhenyan Han, Shuang Sui, Analysis on the existing problems and countermeasures of rural waste management, Guide to Economic Research 2017(7):17-19.

[3] Deyong Wang, Dengyun Yang, The road of building waste resource utilization 2017(8).

[4] Youqian Liang, Thoughts and countermeasures of rural garbage disposal, Environmental Sanitation Engineering 2017(3):42-44.

[5] Xinying Huang, Xiaolong Cai, Yuqin Wei and so on, Aerobic compost and resource utilization of rural household garbage, Shandong Chemical Industry 2017,46(1):133-134. 